\title{
Degradation of Lignosulfonic and Tannic Acids by Ligninolytic Soil Fungi Cultivated under Icroaerobic Conditions
}

\author{
Isis Serrano Silva*, Cristiano Ragagnin de Menezes, Elisangela Franciscon, Eder da Costa \\ dos Santos and Lucia Regina Durrant \\ Departamento de Ciência de Alimentos; Faculdade de Engenharia de Alimentos; Universidade Estadual de \\ Campinas; Rua: Monteiro Lobato, 80; C. P.: 6121; 3083-862; Campinas - SP - Brasil
}

\begin{abstract}
Soil fungi were evaluated regarding their ability to degrade lignin-related compounds by producing the ligninolytic enzymes. Lignosulfonic and tannic acids were used as sole carbon sources during 30 days under microaerobic and very-low-oxygen conditions. The fungi produced lignin-peroxidase, manganese-peroxidase and laccase. Expressive degradations was observed by $C_{18}$ reversed-phase HPLC, indicating the biodegradation potential of these fungi, showing more advantages than obligate anaerobes to decontaminate the environment when present naturally.
\end{abstract}

Key words: lignosulfonic acid, tannic acid, ligninolytic enzymes, microaerobic conditions, soil fungi

\section{INTRODUCTION}

Lignin is a complex polyphenolic macromolecule and a mechanism of support in vegetable tissues, protecting them against the microorganisms. In the nature, white-rot basidiomycete fungi and actinomycetes have ability to degrade lignin (Kajikawa et al., 2000) during the secondary metabolism or in the absence of nitrogen, carbon or sulphur. However, lignin is not degraded as sole carbon and energy sources, requiring additional co-substrate as cellulose, hemicellulose (de Jong et al., 1994) or glucose (Lee, 1997). Several aromatic compounds such as biphenyl, phenols, anysols, diaryl-ethers present in the lignin structure contribute to their irregular and recalcitrant nature. Lignosulphonate compounds are highly hydrophilic macromolecules due to sulfonic acid content, and just a minor fraction of lignosulfonic acid is removed from the water phase by absorption onto organic carbon, sediments or water treatment. They cause aquatic unbalance since surface sunlight is not available to the photosynthetic algae and bacteria as a result of an intense brown-color into the water. Lignosulfonic acids contain a great amount of woodcarbohydrates (e.g. glucose, xylose), nitrogen and mineral nutrients that make of this compound a good alternative as substrate for ligninolytic fungi (Aitken and Logan, 1996). White-rot fungi have been extensively studied for their ability to degrade the lignocellulose by production of ligninolytic enzymes (lignin- and manganeseperoxidases, laccase) and cellulases (Kapich et al., 2004).

Tannins are polyphenolic compounds very

*Author for correspondence: isis@ fea.unicamp.br 
abundant in the vascular plants and very recalcitrant into the nature presenting great resistance to microbial attack (Hernes et al., 2001) since these compounds are capable of complexing with enzymes involved in the degradation process (Bending and Read, 1996a). Tannic acid belongs to hydrolyzed-tannins group, containing glucose molecule linked to gallic acid, showing antinutritional property in herbivorous caused by its ability to associate with proteins, cellulose, hemicellulose, pectin and minerals, retarding digestion (McSweeney et al., 2001) and also forming a complex with other substances containing nitrogen (e.g. aminoacids, peptides, quitin, nucleic acids).

Fungal degradation is considered the main mechanism of biological cycling of lignin, causing oxidation of propyl chains, demethylation of 3and 5-methoxyl groups and aromatic ring cleavage. Brown-rot fungi generate cathecol derivatives as result of demethylation (Filley et al., 2000). Some white-rot fungi have the ability to selectively remove expressive amount of lignin with slight losses of hemicellulose and cellulose, but many others are not selective for lignin degradation.

Phanerochaete chrysosporium is extensively used as a model for the biodegradation of lignin and chemical pollutants by white-rot fungi. The initial depolymerization of lignin is catalyzed by extracellular peroxidases which are responsible for the degradation of several compounds related to lignin structure (Gold and Alic, 1993). The degradation of lignin and phenolic molecules by selective fungi makes them suitable for industrial applications to alter or remove these compounds (Blanchette, 1988). Non-basidiomycete fungi are also good degraders of wood, producing nonspecific extracellular ligninolytic enzymes such as manganese peroxidase and laccase, when grown in media containing lignin-related compounds.

Most fungi need oxygen, at least in small amounts in order to grow; however, some anaerobic phycomycetous fungi capable of degrading lignocellulosic materials are present in the rumen microbiota (Durrant, 1996). Tolerance for low levels of oxygen has also been observed in some aquatic fungi, yeasts and several filamentous fungi such as Fusarium oxysporum, Mucor hiemalis, Aspergillus fumigatus which can fermentate sugars (Singh et al., 1992). The aim of this work was to study the ability of soil fungi to degrade lignosulfonic and tannic acids and produce ligninolytic enzymes under microaerobic conditions.

\section{MATERIALS AND METHODS}

Filamentous fungal cultures such as Achremonium sp, Aspergillus sp, Fusarium oxysporum, Trichoderma sp, Verticillium sp, Trichocladium canadense and and a basidiomycetous H2 (Durrant, 1996) were used in this work. Cultures were cultivated in $0.2 \%$ lignosulfonic acid (LA) or tannic acids (TA) as sole carbon sources in a defined liquid medium containing per liter: $\mathrm{KH}_{2} \mathrm{PO}_{4}(1 \mathrm{~g}) ;\left(\mathrm{NH}_{4}\right)_{2} \mathrm{HPO}_{4}$ $(0.5 \mathrm{~g}) ; \mathrm{CaCl}_{2}(0.3 \mathrm{~g})$; L- cysteine chloridrate as reducing oxygen agent $(1 \mathrm{~g})$; resazurine $0.1 \%$ as reduction indicator dye $(1 \mathrm{ml})$; micronutrients solution $(1 \mathrm{ml})$; vitamins solution $(0.5 \mathrm{ml})$, $\mathrm{pH} 5.5$ 6.0. Both micronutrients and vitamins solutions were previously sterilized by filtration (Millipore membrane, $0.22 \mu \mathrm{m}$ ). The microelements solution was composed by the following salts per liter: ammonium tartarate $(0.22 \mathrm{~g}$; manganese sulphate $(0.66 \mathrm{~g})$; iron sulphate $(0.15 \mathrm{~g})$; cobalt sulphate $(0.10 \mathrm{~g})$; zinc sulphate $(0.10 \mathrm{~g})$; cooper sulphate $(0.64 \mathrm{~g})$ and aluminium potassium sulphate (10.0 g). The vitamins solution was provided also per liter by thiamine $(5.0 \mathrm{~g})$; biotine $(2.0 \mathrm{~g})$; nicotinic acid $(5.0 \mathrm{~g})$; cianocobalamine $(0.1 \mathrm{~g})$; folic acid $(2.0 \mathrm{~g})$; riboflavine $(5.0 \mathrm{~g})$; pyridoxine (10.0 g); DL- pantetonate $\mathrm{Ca}^{+2}(5.0 \mathrm{~g})$ e thiotic acid $(5.0 \mathrm{~g})$. Fungi were grown previously on Malt Extract Agar plates for $7-10$ days at $30^{\circ} \mathrm{C}$, and $3 \times 1 \mathrm{~cm}^{2}$ of mycelia were used as inoculum in each experimental flask. Microaerobic and very-lowoxygen conditions were performed using Lcisteyne chloridrate and resazurine into the medium as described previously, together with microaerobac plates (Probac-Brazil) into the jars. The oxygen generation was 5 through $15 \% \mathrm{O}_{2}$, and less than $1 \%$ when very-low-oxygen condition was applied. Oxidation-reduction reaction produced hydrogen and carbon dioxide after the addition of distilled water into microaerobac or anaerobac plates and jars were sealed immediately afterwards. Microaerobic and very-low-oxygen conditions were then verified by observing the disappearance of resazurin color into the control non-inoculated liquid medium.

Samples were taken on the $30^{\text {th }}$ days for both the conditions for the enzymatic activities analyses and to verify LA and TA degradations. Abiotic 
controls were prepared in the same manner as the samples, except inoculating the mycelia. Supernatants of each sample were centrifuged under refrigeration at 5,541 $\mathrm{g}$ for 15 minutes and stored at $-20{ }^{\circ} \mathrm{C}$ for subsequent HPLC analyses. Enzymatic assays were carried out immediately after each sampling. All the experiments were run in duplicate, including abiotic controls.

Lignin-peroxidase activity (LiP, EC1.11.1.14) was assayed by the determination of veratryl alcohol oxidation to veratryl aldeide (Tien and Kirk, 1993 - modified). Briefly, in a $1 \mathrm{ml}$ - cuvette containing culture supernatant $(0.6 \mathrm{ml})$ was added veratryl alcohol $(2 \mathrm{mM})$ in tartaric buffer $(0.4 \mathrm{M}-\mathrm{pH} 3$; $0.2 \mathrm{ml})$, followed by $2 \mathrm{ml} \mathrm{H}_{2} \mathrm{O}_{2}(2 \mathrm{mM})$. After 10 minutes of reaction, absorbances of samples were read at $310 \mathrm{~nm}$.

Manganese-peroxidase activity (MnP, EC1.11.1.1) was determined by the phenol red oxidation (Kuwahara et al., 1984 - modified), reacting in a cuvette the culture supernatant $(0.5 \mathrm{ml}), 0.25 \mathrm{M}$ sodium lactate $(0.1 \mathrm{ml}), 2 \mathrm{mM} \mathrm{MgSO}{ }_{4}(0.05 \mathrm{ml})$, $5 \%$ bovine albumine $(0.2 \mathrm{ml}), 2 \mathrm{mM} \mathrm{H}_{2} \mathrm{O}_{2}$ in succinate buffer( $0.2 \mathrm{M}-\mathrm{pH} 4.5 ; 0.05 \mathrm{ml})$, with phenol red $1 \%(0.1 \mathrm{ml})$. After 5 minutes of reaction, $40 \mu \mathrm{l}$ of $2 \mathrm{~N} \mathrm{NaOH}$ was added to stop the reaction, and samples absorbances were read at $610 \mathrm{~nm}$.

Laccase (Lac, EC1.10.3.2) was measured via $\mathrm{H}_{2} \mathrm{O}_{2}$-independent oxidation of syringaldazine to its quinone form (Szklarz et al., 1989) by adding to $0.6 \mathrm{ml}$ of culture supernatant in a cuvette, $0.2 \mathrm{ml}$ of $0.05 \mathrm{M}$ citrate-phosphate buffer ( $\mathrm{pH} 5), 0.1 \mathrm{ml}$ of distilled water, and $0.1 \mathrm{ml}$ of seringaldazine in $0.1 \%$ absolute ethanol. After 10 minutes, the reaction was measured at $525 \mathrm{~nm}$.

Enzyme activities were expressed in $\mathrm{U}^{-1}$ that means $\mu \mathrm{mol}$ of substrate oxidized per minute of reaction, according to the followed equation: Enzymatic activity $\left(\mathrm{U} \mathrm{l}^{-1}\right)=\left(\Delta\right.$ Abs $\left.10^{6}\right)(\varepsilon \mathrm{R} \mathrm{T})^{-1}$, when $\Delta \mathrm{Abs}$ is the difference between final and initial absorbencies, $\varepsilon$ is the molar extinction coefficient of each enzyme (LiP- $\varepsilon_{310}=9300 \mathrm{M}$ ${ }^{1} . \mathrm{cm}^{-1} ; \mathrm{MnP}-\varepsilon_{610}=4460 \mathrm{M}^{-1} \cdot \mathrm{cm}^{-1} ;$ Lac- $\varepsilon_{525}=$ $\left.65000 \mathrm{M}^{-1} \cdot \mathrm{cm}^{-1}\right), \mathrm{R}$ is the volume in $\mathrm{ml}$ of supernatant, and $\mathrm{T}$ is the time of reaction in minutes.

HPLC analyses were performed using LC6A chromatographer (Shimadzu) and column Microsorb MV-100 (0.46 cm x $15 \mathrm{~cm}$ x $0.2 \mu \mathrm{m})$ on $\mathrm{C}_{18}$ reverse-phase (Varian). Supernatant of samples containing LA were diluted (1:20), filtered in $0.22 \mu \mathrm{m}$ Millipore membrane and injected $(20 \mu \mathrm{l})$. TA was extracted from the cultures supernatant using propanol in 5\% heptane $\left(\mathrm{v} \mathrm{v}^{-1}\right)$, followed by centrifugation and solvent evaporation under nitrogen flow and re-suspension of the extract in the mobile phase. LA and TA degradations were determined by isocratic elution in methanol: water (30:70), flow rate of $0.1 \mathrm{ml}$ $\mathrm{min}^{-1}$ and UV absorbance detector set at $254 \mathrm{~nm}$. Percentages of degradation were calculated as: \% degradation $=[(\mathrm{PAH}$ control $-\mathrm{PAH}$ sample $) / \mathrm{PAH}$ control] x 100 .

\section{RESULTS AND DISCUSSION}

Soil fungi were capable of growing in liquid medium containing LA as sole carbon source during 30 days, followed by acidification of the media, reaching $\mathrm{pH}$ values less than 3.0 (data not shown). The ligninolytic enzymes might have been produced in this period, and the drop of $\mathrm{pH}$ values suggested the production of acid metabolites by the fungi under microaerobic conditions (Pavarina and Durrant, 2002). Some color changes were also observed possibly due to the production of colored metabolites, or reaction with medium components, or with the respective carbon sources (Silva, 2002). The brown color into the medium might also be a consequence of re-polymerization of degradation products by extracellular phenoloxidases (Bending and Read 1996 a,b).

In the present study, Verticillium sp reached the best rates of degradation when grown in LA (27.5 and $32.5 \%)$, as well as higher levels of LiP (18.12 and $8.70 \mathrm{U} \mathrm{l}^{-1}$ ) under microaerobic and very-lowoxygen conditions, respectively, as indicated in Figures 1 and 3a.

Aspergillus sp also showed good degradation of LA (26.5\%), and highest level of laccase compared with the other strains studied. The basidiomycetous $\mathrm{H} 2$ showed high activities of LiP, $\mathrm{MnP}$ and laccase and low LA degradation under microaerobic condition.

The microaerobic fungus Trichocladium canadense reached good degradation under low oxygenation condition (Figures 1 and $3 b$ ); however, only activity of laccase was detected in this period. It occurred probably due to a previous production of more specific enzymes under low rates of oxygen that were able to degrade LA. On other hand, it was possible that ligninolytic enzymes could help this degradation; however, not as a key-hole in the process. 


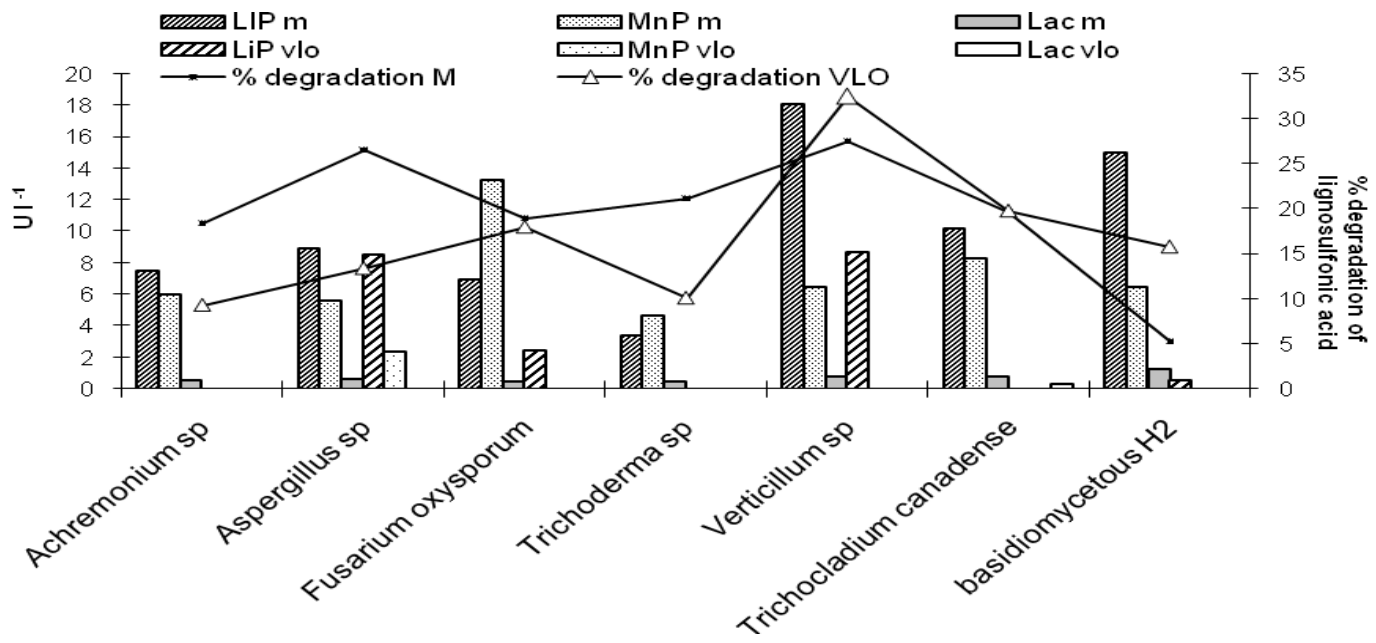

Figure 1 - Maxima activities of lignin-peroxidase (LiP), manganese-peroxidase (MnP) and laccase (Lac) produced by fungi during 30 days of cultivation and \% of lignosulfonic acid (LA) degradation under a microaerobic $(\mathrm{m})$ and very-low-oxygen (vlo) conditions. All data showed means with $95 \%$ of confidence interval.

Trichoderma sp and Achremonium sp did not show any activity of ligninolytic enzymes under verylow-oxygen condition; however, LA degradations were detected after 30 days of cultivation (10.1 and $9.3 \%$, respectively).

Filamentous fungi, especially Aspergillus niger and Penicillium ssp were capable of growing in TA as sole carbon source. Some non-white-rot fungi have been described as the very good degraders of TA in static cultures (Bhan et al.,
1997; Bhat et al., 1998; Falconi, 1998). In this study, Achremonium sp, Fusarium oxysporum and Verticillium sp showed best visual growths in TA as sole carbon source under microaerobic condition with considerable drop of $\mathrm{pH}$ values (data not shown). High levels of $\mathrm{MnP}$ were detected in supernatants of Trichoderma sp, Achremonium sp and $\mathrm{H} 2$ strain. Nevertheless, these fungi showed the lowest degradation under microaerobic condition (Fig.2).

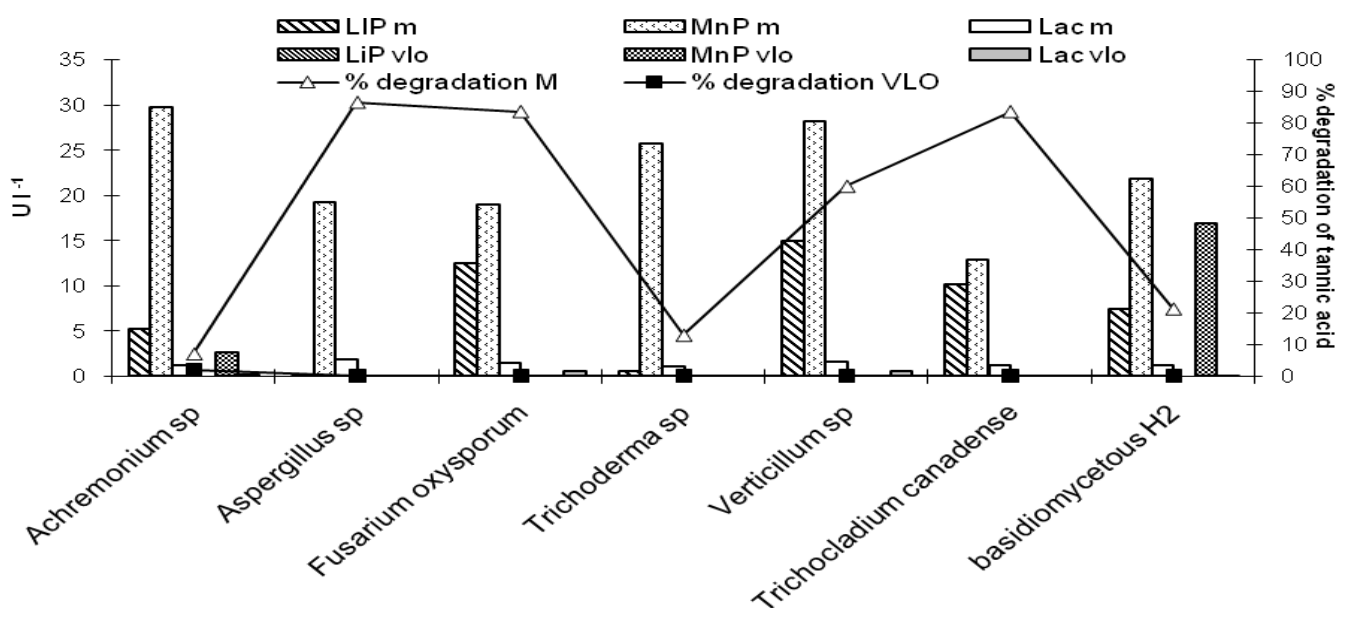

Figure 2 - Maxima activities of lignin-peroxidase (LiP), manganese-peroxidase (MnP) and laccase (Lac) produced by fungi during 30 days of cultivation in tannic acid (TA) and rates of its degradation under a microaerobic $(\mathrm{m})$ and a very-low-oxygen (vlo) conditions. All data showed means with $95 \%$ of confidence interval. 
It is believed that $\mathrm{MnP}$ could be produced as part of the fungi constitutive metabolism with no direct relation with TA degradation in this case. Some fungi such as Chaetomium, Fusarium, Rhizoctonia, Cylindrocarpon, Trichoderma and Candida are also able to degrade tannic compounds (Saxena et al., 1995). Fusarium oxysporum, Aspergillus sp (Fig. 4a) and Trichocladium canadense (Fig. $4 \mathrm{~b}$ ) were the best degraders of TA producing ligninolytic enzymes, excepting LiP by Aspergillus sp. The strain H2 showed activities of $\mathrm{MnP}$ and laccase under verylow-oxygen; however, did not show any TA degradation.
During the lignin degradation, several simultaneous reactions are involved in the oxidation, polymerization and complete mineralization, producing and accumulating metabolic intermediates (Hernandéz-Péres et al., 1998). Aromatic rings cleavage is the main mechanism to degrade the lignin in sulfatereducing sediments (Dittmar and Lara 2001). Lignin degradation by anaerobic fungi from rumen of herbivorous resulted in a breakdown of esterand eter- linkages from phenolic units forming phenolic acids with no degradation of the most abundant linkages between lignin and wood polysaccharides (McSweeney et al., 1994).
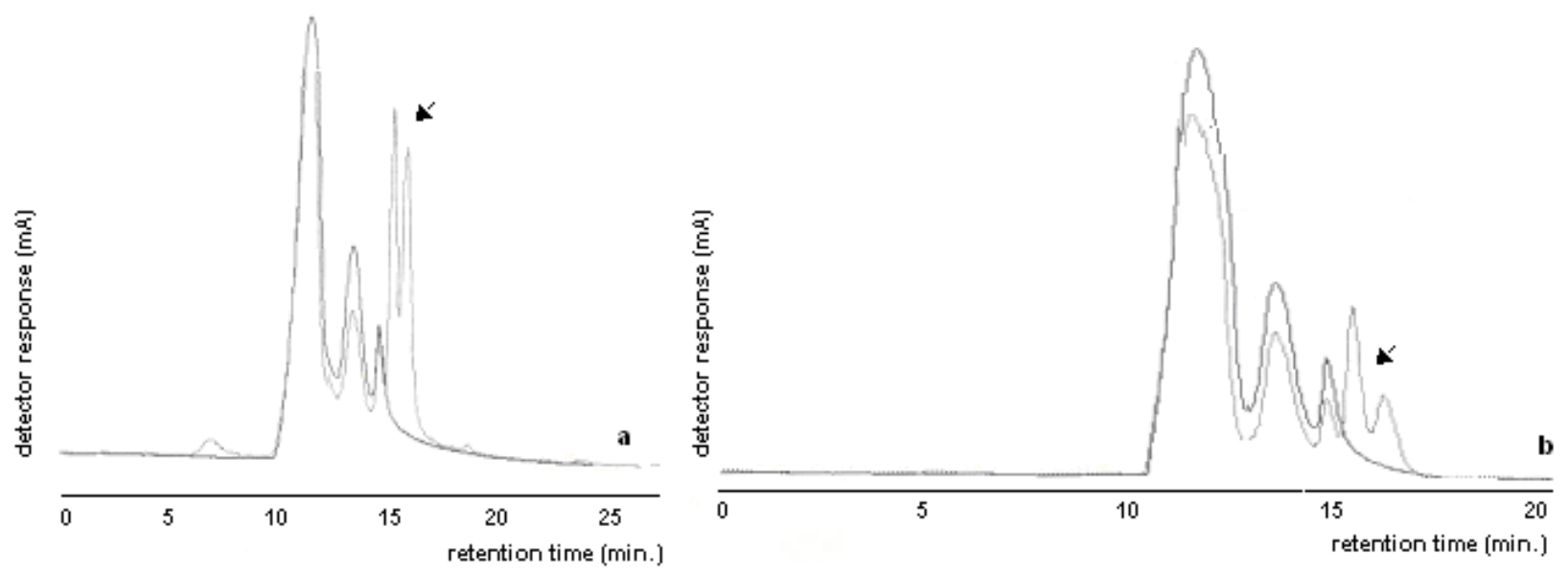

Figure 3 - Chromatograms showing degradation of lignosulfonic acid by Verticillium sp (a) and Trichocladium canadense (b) followed by 30 days of cultivation under very-lowoxygen condition indicated by the weak line. Metabolic intermediates are indicated by arrows. Abiotic control is shown in dark line.
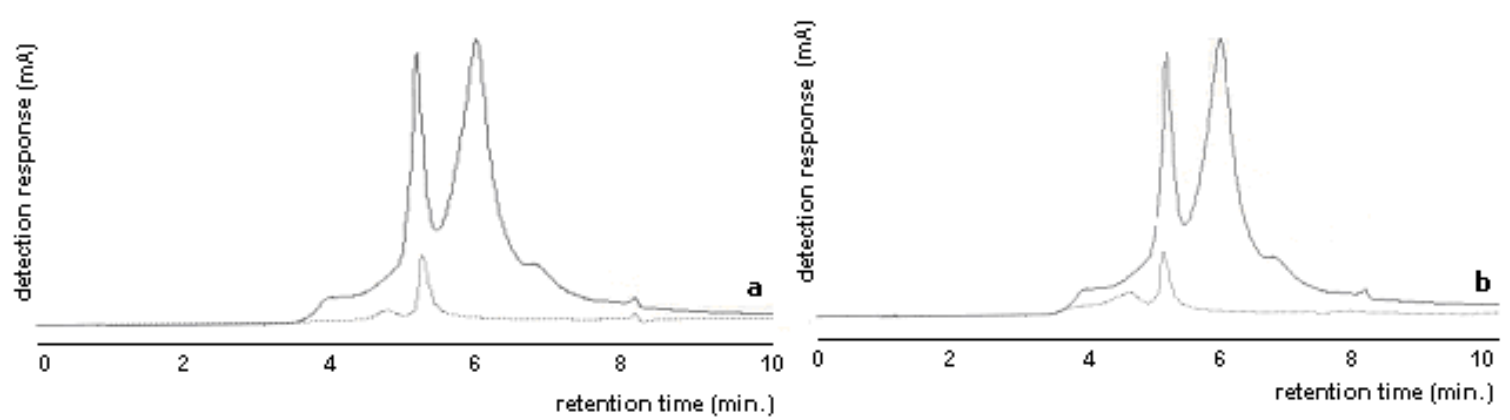

Figure 4 - Chromatograms showing degradation of tannic acid by Aspergillus sp (a) and Trichocladium canadense (b) followed by 30 days of cultivation under microaerobic condition indicated by the weak line. Abiotic control is shown in dark line. 
Similar results of LA degradation by nonbasidiomycete fungi under non-oxygenated condition were also observed in other studies, verifying the degradation under microaerobic condition (Falconi, 1998; Sette, 1997). However, these results were lower than results confirmed in the present study. The microaerobic fungi Trihcocladium canadense and $\mathrm{H} 2$ were also able to grow in LA and produce laccase and other peroxidases (Durrant, 1996). Fungi may produce different enzymes depending on genetic characteristics or environment conditions (Eggen, 1999),. Therefore, it is likely that other enzymes are activated under this condition and ligninolytic enzymes may also help in LA degradation.

\section{CONCLUSIONS}

From results, it could be concluded that ligninolytic enzymes were produced during the degradation process, acting on metabolic intermediates. Apparently tannase and some other specific enzymes to degrade TA were probably activated to promote the degradation of TA under limitation of oxygen. Further studies are required regarding others enzymatic systems involved in this process.

\section{ACKNOWLEDGEMENTS}

The authors would like to thank FAPESP (Brazilian Foundation for Research Support, Sao Paulo, Brazil) for the master degree scholarship to Ms Isis Silva and for the financial support to this work.

\section{RESUMO}

Fungos isolados de solo foram avaliados quanto à habilidade em degradarem compostos derivados de lignina pela produção de enzimas ligninolíticas. Os ácidos lignosulfônicos e tânico foram usados separadamente como única fonte de carobono para cultivo dos fungos em 30 dias sob condições microaeróbias. Os fungos foram capazes de crescer e usar tais compostos como fonte de carbono e mostraram produção de ligninaperoxidase, manganês-peroxidase e lacase. Degradações expressivas dos ácidos lignosulfônico e tânico foram verificadas por Cromatografia Liquida de Alta Eficiência (CLAE), indicando grande potencial de uso em processos de biorremediação de macromoléculas aromáticas similares à lignina em ambientes naturais sob condições baixas de oxigenação.

\section{REFERENCES}

Aitken, M.D. and Logan, B.E. (1996), Degradation of pentachlorophenol by the white rot fungus Phanerochaete chrysosporium grown in ammonium lignosulphonate media. Biodegradation, 7, 175-182.

Bending, G.D. and Read, D.J. (1996a), Effects of the soluble polyphenol tannic acid on the activities of ericoid and ectomycorrhizal fungi. Soil Biol. Biochem., 28, 1595-1602.

Bending, G.D. and Read, D.J. (1996b), Nitrogen mobilization from protein-polyphenol complex by ericoid and ectomycorrhizal fungi. Soil Biol. Biochem, 28, 1603-1612.

Bhan, T.K., Makkar, H.P.S. and Singh, B. (1997), Preliminary studies on tannin degradation by Aspergillus niger van Tieghem MTCC 2425. Lett. Appl. Microbiol., 25, 22-23.

Bhat, T.K., Singh, B. and Sharma, O.P. (1998), Microbial degradation of tannins: a current perspective. Biodegradation, 9, 343-357.

Blanchette, R.A., Burnes, T.A., Leatham, G.F. and Effland, M.J. (1988), Selection of white-rot fungi for biopulping. Biomass, 15, 93-101.

de Jonge, E., Field, J.A. and de Bont, J.A.M. (1994), Aryl alcohols in the physiology of ligninolytic fungi. FEMS Microbiol. Rev., 13, 153-188.

Dittmar, T. and Lara, R.J. (2001), Molecular evidence for lignin degradation in sulfate-reducing mangrove sediments (Amazônia, Brazil). Geochim. Cosmochim. Acta, 65, 1417-1428.

Durrant, L.R. (1996), Ethanol production from cellulose by two lignocellulolytic soil fungi. Appl. Biochem. Biotech., 57, 399-406.

Eggen, T. (1999), Application of fungal substrate from commercial mushroom production -Pleuorotus ostreatus - for bioremediation of creosote contaminated soil. Int. Biodet. Biodegrad., 44, 117126.

Falconi, F.A. (1998), Bioconversão de compostos fenólicos por fungos ligninolíticos, MSc Thesis, State University of Campinas, São Paulo, Brazil.

Filley, T.R., Hatcher, P.G., Shortle, W.C. and Praseuth, R.T. (2000), The application of 13C-labeled teramethylammonium hydroxide (13C-TMAH) thermochemolysis to the study of fungal degradation of wood. Organic Geochem., 31, 181-198. 
Gold, M.H. and Alic, M. (1993), Molecular biology of the lignin-degrading basidiomycete Phanerochaete chrysosporium. Microbiol. Rev., 57, 605-622.

Hernandéz-Péres, G., Goma, G. and Rols, J.R. (1998), Enhanced degradation of lignosulfonated compounds by Streptomyces viridosporus. Water Sci. Technol., 38, 289-297.

Kajikawa, H., Kudo, H., Kondo, T., Jodai, K., Honda, Y., Kuwahara, M. and Watanabe, T. (2000), Degradation of benzyl ether bonds of lignin by ruminal microbes. FEMS Microbiol. Lett., 187, 1520.

Kapich, A.N., Prior, B.A., Botha, A., Galkin, S., Lundell, T. and Hatakka, A. (2004), Effect of lignocellulose-containing substrates on production of ligninolytic peroxidases in submerged cultures of Phanerochaete chrysosporium ME-446. Enzyme Microbial Tech., 34, 187-195.

Kuwahara, M., Glenn, J.K., Morgan, M.A. and Gold, M.H. (1984), Separation and characterization of two extracellular $\mathrm{H}_{2} \mathrm{O}_{2}$ dependent oxydases from ligninolytic cultures of Phanerochaete chrysosporium. FEBS Microbiol. Lett., 169, 247-250.

Lee, J. (1997), Biological conversion of lignocellulosic biomass to ethanol. J. Biotech., 56, 1-24.

McSweeney, C.S., Dulieu, A., Katayama, Y. and Lowry, J.B. (1994), Solubilization of lignin by the ruminal anaerobic fungus Neocallimastix patriciarum. Appl. Environ. Microbiol., 60, 29852989.

McSweeney, C.S., Palmer, B., MnNeill, D.M. and Krause, D.O. (2001), Microbial interactions with tannins: nutritional consequences for ruminants. Animal Feed Sci. Tech., 91, 83-93.
Pavarina, E.C. and Durrant, L.R. (2002), Growth of lignocellulosic-fermenting fungi on different substrates under low oxygenation conditions. Appl. Biochem. Biotechnol., 99, 663-678.

Saxena, R.K., Sharmila, P. and Singh, V.P. (1995), Microbial degradation of tannins. Progress in Ind. Microbiol., 32, 259-270.

Sette, L.D. (1997), Estudo do sistema ligninolítico produzido por fungos sob diferentes condições de oxigenação, MSc. Thesis, State University of Campinas, Sao Paulo, Brazil.

Silva, I.S. (2002), Fungos degradadores de compostos orgânicos recalcitrantes sob condições microaeróbia e anaeróbia, MSc thesis, State University of Campinas, São Paulo, Brazil.

Singh, A., Kuman, P.K. and Schuger, K. (1992), The oxygen requirement of Fusarium oxysporum for the fermentation of D-xylose and D-glucose. Biotech. Appl. Biochem., 16, 296-302.

Szklarz, G.D., Antibus, R.K., Sinsabaugh, R.L. and Linkins, A. E. (1989), Production of phenoloxidases and peroxidases by wood-rotting fungi. Mycol., 81, 234-240.

Tien, M. and Kirk, T.K. (1993), Lignin-degrading enzyme from the Hymenomycete Phanerochaete chrysosporium burds. Science, 221, 661-663.

Received: September 25, 2007; Revised: June 30, 2008; Accepted: August 13, 2009. 